\title{
Effect of Birhi Vaiety of Date Palm Fruits, (Phoenix dactylifera L.) at the Tamr Stage on Serum Glucose Levels in Streptozotocin-Induced Diabetic Rats
}

\author{
Mohammed O. Ibrahim ${ }^{1}$, Mousa N. Ahmad ${ }^{2}$, Hani J. Hamad ${ }^{1} \&$ Wasfy J. Hamad ${ }^{3}$ \\ ${ }^{1}$ Department of Food Science and Nutrition, Faculty of Agriculture, Jerash University, Jerash, Jordan \\ ${ }^{2}$ Department of Nutrition and Food Technology, Faculty of Agriculture, The University of Jordan, Amman, \\ Jordan \\ ${ }^{3}$ Pulmonary, Critical Care and Respiratory Medicine, Alkhor Hospital, Alkhor, Qatar \\ Correspondence: Mohammed O. Ibrahim, Department of Food Science and Nutrition, Faculty of Agriculture, \\ Jerash University, P.O. Box 311, Jerash 26110, Jordan. Tel: 962-780-896-371. E-mail: \\ mohammed_omar_81@yahoo.com
}

Received: October 26, 2015 Accepted: November 20, 2015 Online Published: December 15, 2015

doi:10.5539/jas.v8n1p110 URL: http://dx.doi.org/10.5539/jas.v8n1p110

\begin{abstract}
This study was carried out to investigate the effect of a dietary preparation of Birhi tamr (Phoenix dactylifera L.) on serum glucose levels and body weight in normal, diabetic insulin-treated and diabetic insulin-untreated rats. Diabetes was partially induced by intraperitoneal injection of streptozotocin $(32.25 \mathrm{mg} / \mathrm{kg})$. Thirty six male Sprague-Dawley rats $(239 \pm 8.4 \mathrm{~g})$ were divided into two normal, two diabetic insulin-treated and two diabetic insulin-untreated groups. Each group was fed a diet containing either $0 \%$ or $10 \%$ tamr for six weeks. Fasting serum glucose levels were determined by enzymatic-calorimetric method using a standard kit procedure.Feeding $10 \%$ tamr did not show significant differences $(\mathrm{P}>0.05)$ in serum glucose levels in any of the normal and insulin-treated diabetic rats. Insulin-untreated diabetic rats fed $0 \%$ tamr or $10 \%$ tamr exhibited significantly $(\mathrm{P}<$ $0.05)$ higher serum glucose levels $(496 \pm 81.6,315 \pm 61.1 \mathrm{mg} / \mathrm{dl}$ respectively) compared to normal (147 \pm 5.3 , $156 \pm 7.6 \mathrm{mg} / \mathrm{dl}$ respectively) and insulin-treated diabetic rats $(227 \pm 17.6,268 \pm 18.9 \mathrm{mg} / \mathrm{dl}$ respectively). Feeding $10 \%$ tamr to insulin-untreated rats induced significant $(\mathrm{P}<0.05)$ reduction in this variable. The findings of the present study may provide support for the favourable effect of date palm fruits as tamr, on blood glucose in streptozotocin-diabetic rats. This effect cannot be simply explained on the basis of the macro-nutrient composition of tamr. However, due to the apparent effects of tamr on blood glucose in normal and insulin-treated and insulin-untreated diabetic rats, the possible presence of insulin-like substance in tamr may not be excluded. The mechanism of action of the blood glucose-lowering effect of tamr awaits further investigation.
\end{abstract}

Keywords: date palm fruit, Birhi vaiety (Phoenix dactylifera L.), streptozotocin (STZ), serum glucose, sprague-dawley rat

\section{Introduction}

Diabetes mellitus is a major health problem worldwide (ADA, 2002). It is a major cause of death in many countries, and presents a serious health concern in Jordan (Ajlouni et al., 1998; Ajlouni et al., 1999). The disease is associated with abnormal changes in protein, carbohydrate and fat metabolism (Dominique et al., 2003) and induce disturbances in lipid profiles especially, an increased susceptibility to lipid peroxidation (Drisko et al., 2003), as well as body weight defects (ADA, 2002). Diabetes accounts for a substantial burden of morbidity and mortality through micro- and macro vascular complications (Gaede et al., 2003; Heymann et al., 2006). The most common chronic complications of diabetes include retinopathy, nephropathy, neuropathy and atherosclerosis (Al-Shamsi et al., 2007). Animals receiving streptozotocin exhibit metabolic and clinical manifestations reminiscent of human diabetes (Szkudelski \& Szkudelska, 2002).

Diet is the cornerstone of diabetes management. The aim of dietary therapy is to improve metabolic control and lessen the adverse effects of diabetes on the homeostasis of body weight and blood glucose (ADA, 2002). Efforts are now being exerted to produce a diet formula that best controls the disease and its complications. A more recent view to the subject is the attempts of introducing functional foods to the diabetic diets (Hill and Peters, 
2002). A food can be regarded as "functional" if it is satisfactorily demonstrated to affect beneficially one or more target functions in the body, beyond adequate nutrition, in a way that improves health and well-being or reduce the risk of disease (Roberfroid, 2000).

Dates (Phoenix dactylifera L.) have been an important crop in the desert regions of Middle Eastern countries and formed the basis of survival of many ancient nomads (Al-Hooti et al., 2002). Even today, dates continue to play an essential role in the diet of the local inhabitants (Ahmed et al., 1995). Dates are still a dietary staple of the people of this area, and are frequently referred to "the bread of the desert" (Al-Shahib \& Marshall, 2003). Palms represent the third most important plant family with respect to human use (Johnson, 1998). The fruits are commonly consumed as fresh dates at the khalal and rutab stages, or as dry fruits at the tamr stage (El-Shaarawy, 1989; Ahmed et al., 1995). Dates are also consumed in other forms particularly date paste and syrup (El-Shaarawy, 1989), date chutney (Sawaya et al., 1989), tamaroggt (Al-Ruqaie \& El-Nakhal, 1989) and jam (Mustafa et al., 1983a). They may also be used as a sweetening and/or flavoring agent in ice cream (Hamad et al., 1983), bakery products, juices (Mustafa et al., 1983b) and milk beverages (Yousif et al., 1989). Birhi variety of dates is the major variety produced by Jordanian farmers (Naber, 2005).

Dates contain high percentages of carbohydrates and appreciable level of dietary fibers, with some mineral elements and vitamins as well as a good protein level with twenty three different amino acids (Al-Shahib \& Marshall, 2003). The fruit also contains several active phytochemicals such as polyphenols, sterols, tannins and carotenoids (Vayalil, 2002).

In spite of the long history of dates as nutritional staple in the Middle East, most of the published studies on it have dealt mainly with its nutritional value and its uses in food industry (Al-Shahib \& Marshall, 2003). Dates are included in the list of the folk remedies as a dietary factor that protects against heart disease, with possible anti-diabetic effects, though scientific reasonings behind this use are not known (Amer, 1994). In clinical settings, diabetic patients are commonly advised to reduce or even avoid the ingestion of dates to prevent presumed wide fluctuations in blood glucose level. The apparent reason behind this advice is the high carbohydrate content of dates, mainly in the form of sugars. However, there is no scientific evidence available to validate such a dietary restriction.

Contrary to the usual belief, dates are classified as low glycemic index food items (Miller et al., 2002, 2003). The index varies depending on the variety and the stage of ripening. The glycemic indices in normal subjects were 35.5 for khalas, 49.7 for Birhi and 30.5 for ma'an date varieties (Miller et al., 2002); 47.2 for Khalas Rutab and 28.9 for Khalas Tamr/yoghurt preparation (Miller et al., 2003). For the commercially stored Khalas date variety, the index was 57.7 in both diabetic and normal subjects (Ahmed et al., 1991). The low glycemic index of dates may be attributed to their high content of fructose and dietary fiber, and perhaps to other microchemicals contained in dates.

To the best of our knowledge, no studies are available to indicate the effect of date palm fruits, incorporated as part of the diet, on blood glucose and body weight homeostasis in diabetic men and animals. Studies of the metabolic responses to dates and the effect of their incorporation into mixed diets in normal and diabetic man or animals are also lacking. This study was conducted to evaluate the effect of tamr of Birhi dates incorporated as part of the diet on blood glucose levels in streptozotocin-induced diabetic rats.

\section{Methods}

\subsection{Date Collection and Preparation}

A quantity of locally produced Birhi date from the tamr stage of ripening was obtained from a local farm in due season, 2005 (Al-Baraka Farms, Jordan). Dates were stored in sealable bags (Zepter-Vacsy bag, Korea) under vacuum (Zepter-Vacsy, Italy). The packages were then deep frozen $\left(-20^{\circ} \mathrm{C}\right)$ for subsequent analysis and diet preparation (Al-Mashhadi et al., 1993).

Date sample representing the tamr stage of ripening were taken, and were bitted before the flesh was ground up separately in a food grinder (National, MK-G30NR, Japan). The ground samples of tamr were dried in a drying oven (Memmert, Karlklob-West Germany) at $70{ }^{\circ} \mathrm{C}$ until constant weights were obtained. After drying, they were ground separately to powder using pestle and mortar and placed in sealed polythene bags in desiccators (Al-Shahib \& Marshall, 2002).

\subsection{Chemical Analysis of Dates}

Proximate nutrient composition of dried Birhi Tamr was determined by using the official methods set by the Association of Official Analytical Chemists (AOAC, 1995). Moisture content of dates of tamr stages was obtained using drying-oven method. Nitrogen content of oven-dried samples of tamr was obtained using the 
micro Kjeldahl method (AOAC, 1995). Crude fat content of oven-dried samples of tamr was determined using the Soxhlet extraction method (AOAC, 1995). Crude ash content of oven-dried samples of tamr was obtained using the dry ashing method. Crude fiber content of dried samples of tamr was obtained by the Van Soest method. Nitrogen-free extract that represents the soluble carbohydrates, was calculated by difference, subtracting the sum of crude protein, crude fat, crude fiber and crude ash content from $100 \%$.

\subsection{Preparation of Experimental Diet Mixtures}

Two experimental diet mixtures were prepared that have isocaloric, isonitrogenous and isonutrient (proteins, vitamins and mineral elements) content. They contained $0 \%$ or $10 \%$ of tamr. The experimental diet mixtures were composed of specific amounts of dried egg albumin, corn starch, corn oil, fat-soluble vitamin mixture, water-soluble vitamin mixture, mineral mixture, DL-methionine, and fresh dates from tamr. They were thoroughly mixed in a stainless steel blender (Kenwood, Hampshire, England).

Table 1 shows the ingredient composition of the two experimental diet mixtures. The nutrient composition of the dried egg-albumin (Enthoven, Raalte, Holland) and the dried date preparations were considered in the formulation of diet mixtures. Fresh date preparations of tamr were incorporated into the diet mixtures. However, for the purpose of formulation of diet composition and calculation of nutrient intakes, the nutrient composition of dried dates was considered. The composition of vitamin and mineral mixture was according to Reeves (1997). The protein and caloric content of diet mixtures were $18 \%$ and $425 \mathrm{Kcal} / 100 \mathrm{~g}$ respectively. Table 2 shows the calculated proximate nutrient composition of the diets used in the experiment. The experimental diet mixtures were freshly prepared twice a week and stored in a refrigerator at $4{ }^{\circ} \mathrm{C}$ until needed during the feeding stage. Diets were added daily in amounts depending on the daily intake of rats.

Fresh tamr was bitted and ground (National, MK-G30NR, Japan) just before preparing the diets. It was intended to incorporate fresh date into the diet mixtures to preserve their micro-components that might be affected by drying (Caro et al., 2004). In order to do so, known amounts of corn starch and fresh tamr were separately mixed and allowed to pass through a sieve of $1 \mathrm{~mm}$ mesh to obtain homogenous mixes. Specific amounts of these mixes were used in diet preparation. Mixes of starch and fresh dates were prepared just prior to diet preparation.

Table 1. Ingredient composition of experimental diets

\begin{tabular}{|c|c|c|}
\hline \multirow{2}{*}{ Component } & \multicolumn{2}{|c|}{ Diet mixtures $(\mathrm{g} / 100 \mathrm{~g})$} \\
\hline & $0 \%$ Tamr & $10 \% \mathrm{Tamr}$ \\
\hline Albumin & 18.63 & 18.39 \\
\hline Corn starch & 65.07 & 55.81 \\
\hline Corn oil & 9.0 & 8.92 \\
\hline Tamr & 0.0 & 10 \\
\hline Water-soluble vitamin mix ${ }^{(1)}$ & 2.0 & 2.0 \\
\hline Fat-soluble vitamin mix ${ }^{(2)}$ & 1.0 & 1.0 \\
\hline Mineral mix ${ }^{(3)}$ & 4.0 & 4.0 \\
\hline DL-Methionine & 0.3 & 0.3 \\
\hline
\end{tabular}

Note. ${ }^{(1)} 1 \mathrm{~kg}$ water soluble vitamin mix composed of the following: $0.5 \mathrm{~g}$ thiamin hydrochloride, $0.4 \mathrm{~g}$ riboflavin, $45 \mathrm{~g}$ ascorbic acid, $4 \mathrm{~g}$ calcium patathonate, $4 \mathrm{~g}$ nicotinic acid, $2.5 \mathrm{~g}$ choline, $25 \mathrm{mg}$ inositol, $10 \mathrm{~g}$ para-aminobenzoic acid, $0.02 \mathrm{~g}$ biotin, $0.2 \mathrm{~g}$ folic acid, $0.4 \mathrm{~g}$ pyridoxine hydrochloric, $2.5 \mathrm{mg}$ cyanocobalamine, and $0.225 \mathrm{~g}$ menadione (vitamin $\mathrm{K}$ ). Mixture weight was continued to $1 \mathrm{~kg}$ by dextrose (Adapted from Reeves, 1997). ${ }^{(2)}$ Fat soluble vitamin mix composed of the following: $0.25 \mathrm{~g}$ retinyl acetate, $1 \mathrm{ml}$ of solution made by dissolving $0.125 \mathrm{~g}$ vitamin $\mathrm{D} 2$ in $10 \mathrm{ml}$ oil, $2 \mathrm{~g}$ vitamin $\mathrm{E}$ (DL- $\alpha$-tocopherol acetate) in $500 \mathrm{ml}$ corn oil (or $10 \mathrm{ml}$ fat soluble vitamin mix provide 400IU vitamin A, 1000IU vitamin D2 and 40IU vitamin E) (Adapted from Reeves, 1997). ${ }^{(3)}$ Mineral mix composed of the following: $0.21 \mathrm{~g} \mathrm{AlK}\left(\mathrm{SO}_{4}\right)_{2} \cdot \mathrm{H}_{2} \mathrm{O}, 350 \mathrm{~g} \mathrm{CaCO}_{3}, 250 \mathrm{~g} \mathrm{KH}_{2} \mathrm{PO}_{4}$, $0.26 \mathrm{~g} \mathrm{COCl}_{2} \cdot 6 \mathrm{H}_{2} \mathrm{O}, 0.5 \mathrm{~g} \mathrm{CuSO}_{4} \cdot 5 \mathrm{H}_{2} \mathrm{O}, 9.424 \mathrm{~g} \mathrm{FeSO}_{4} \cdot 7 \mathrm{H}_{2} \mathrm{O}, 49.94 \mathrm{~g} \mathrm{MgSO}_{4}, \mathrm{MnSO}_{4} \cdot 4 \mathrm{H}_{2} \mathrm{O}, 0.25 \mathrm{~g} \mathrm{KI}, 135.48$ $\mathrm{g} \mathrm{K}_{2} \mathrm{HPO}_{4} \cdot 3 \mathrm{H}_{2} \mathrm{O}, 127.58 \mathrm{~g} \mathrm{NaCl}, 0.0635 \mathrm{~g} \mathrm{NaF}, 0.26 \mathrm{~g} \mathrm{Na}_{2} \mathrm{~B}_{4} \mathrm{O}_{7} \cdot 10 \mathrm{H}_{2} \mathrm{O}, 1.65 \mathrm{~g} \mathrm{ZnSO}_{4} \cdot 7 \mathrm{H}_{2} \mathrm{O}, 0.0815 \mathrm{~g} \mathrm{H}_{3} \mathrm{BO}_{3}$,

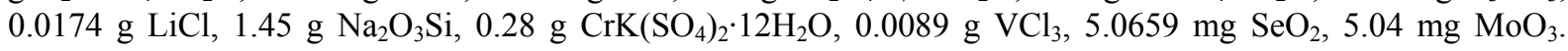
Mixture weight was continued to $1 \mathrm{~kg}$ by dextrose (Adapted from Reeves, 1997). 
Table 2. Calculated nutrient composition of experimental diet mixtures (\%)

\begin{tabular}{lll}
\hline \multirow{2}{*}{ Component } & \multicolumn{2}{c}{ Diet Mixtures (\%) } \\
\cline { 2 - 3 } & $0 \%$ Tamr & $10 \%$ Tamr \\
\hline Protein $^{(1)}$ & 18 & 18 \\
Nitrogen free extract $^{(2)}$ & 65.7 & 65.7 \\
Fat $^{(3)}$ & 9 & 9 \\
Water-soluble vitamin mix $_{\text {Fat-soluble vitamin mix }}$ & 2 & 2 \\
Mineral Mix & 1 & 1 \\
DL-Methionine & 4 & 4 \\
\hline
\end{tabular}

Note. ${ }^{(1)}$ Dried egg albumin, ${ }^{(2)}$ Corn starch, ${ }^{(3)}$ Corn oil.

\subsection{Animal Experimentation}

Adult male rats weighing about $200 \mathrm{~g}$ were individually housed in plastic cages with stainless steel wire-mesh bottoms (B. Holden and Crew 2001, North Kent Plastic Cages Ltd, England). They were fed for two weeks prior to start of the experiment for acclimatization. Environmental conditions were under control with a temperature of $24 \pm 2{ }^{\circ} \mathrm{C}$ and 12 hour light dark cycle. Diets were given in glass jars and water was provided in glass bottles with rubber stoppers.

At the beginning of the experimental feeding stage, thirty six male rats (12 week old) were distributed randomly according to their weights $239 \pm 8.4 \mathrm{~g}$ into 6 groups. Twelve animals were divided into two groups $(6$ rats/each group) and served as the normal groups. Diabetes was partially induced in rats by a single intraperitonial sterptozotocin (2-deoxy-2-\{[(methylnitrosamino)carbonyl]-amino $\}$-D-glucopyranose) (Sigma Chemicals Co., Mo, USA) injection (32.25 mg/ml freshly dissolved in $0.05 \mathrm{M}$ citrate buffer, $\mathrm{pH} 4.5$ at a dose of $32.25 \mathrm{mg} / \mathrm{kg}$ ) (Kanarek \& Ho, 1984; Yamada et al., 2002). After 24 hours, diabetes was checked by testing glucosuria of the rats using glucose urine strips (Glkotest, Rocho Germany) and by observing polydipsia and polyuria. Rats which showed positive glucose urine results were 24 rats. The rest of the rats which showed negative glucose urine results were excluded from the experiment. Diabetic rats (24 rats) were divided into four groups $(6$ rats/each group). Two of the diabetic groups were treated subcutaneously with Insulatard ${ }^{\mathbb{B}} \mathrm{HM}$ at a dose of $10 \mathrm{U} / \mathrm{kg} / \mathrm{day}$ and served as the insulin-treated diabetic groups; the other two diabetic rat groups were lift untreated and served the insulin-untreated diabetic groups. Each diet mixture, described earlier, was given to one normal and one insulin treated and one insulin untreated diabetic groups for a period of six weeks. Figure (1) shows the experimental arrangement of normal and diabetic rats in the study. 


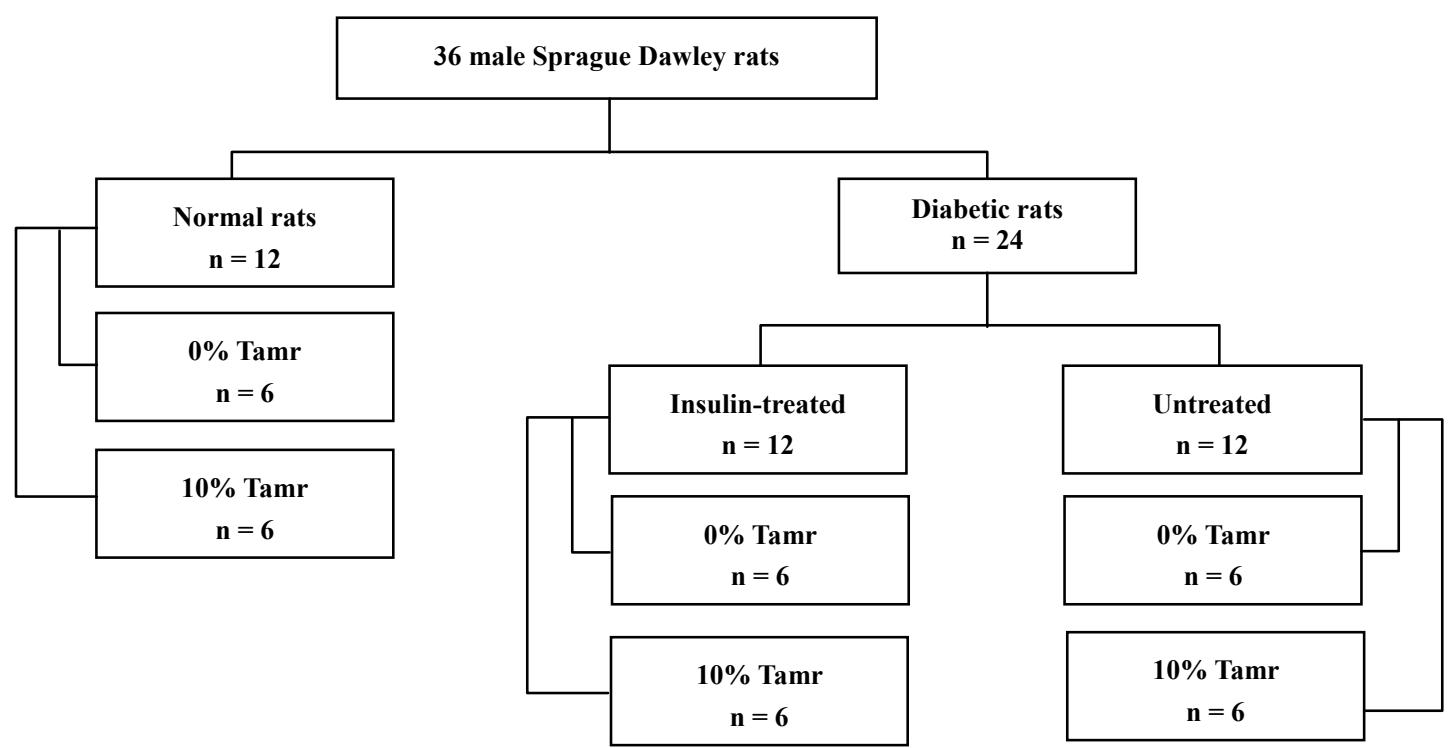

Figure 1. Experimental arrangement of normal and diabetic rats

At the end of six weeks, rats were starved for 8 hours, anesthetized with chloroform, weighed then blood was drawn from right ventricle of the heart using a medicinal syringe and transferred to plain tubes, centrifuged at $3200 \mathrm{rpm}$ for 15 minutes (Clement, ES 150 centrifuge, Australia) to obtain serum. Samples of the serum were stored frozen at $-20{ }^{\circ} \mathrm{C}$ until analysis was performed.

\subsection{Biochemical Analysis of Serum Glucose}

Serum glucose concentration was analyzed in Al-Takhasosi hospital laboratory section Glucose was measured by Cayman's Glucose Colorimetric Assay Kit.

\subsection{Statistical Analysis}

The results of each studied variable were subjected to the analysis of variance (ANOVA) and least significant difference test using the statistical analysis (SAS package version 9) to determine if differences in means were significant at $(\mathrm{P}<0.05)$. The results were presented as means \pm standard error of the mean $(\mathrm{SEM})$.

\section{Results}

\subsection{Proximate Nutrient Composition of Tamr}

Proximate nutrient composition of tamr from Birhi dates is presented in table 3. Moisture content was $17.2 \%$. The proximate nutrient composition of the date tamr stage of ripening on dry matter basis were $2.4 \%$ crude protein, $0.8 \%$ crude fat, $2.0 \%$ crude fiber $2.2 \%$ ash and $92.6 \%$ nitrogen free extract. Calculated energy content of tamr was 387.2 total energy (Kcal/100 gm).

Table 3. Proximate nutrient composition of Birhi tamr ${ }^{(1-3)}$

\begin{tabular}{ll}
\hline Composition & Tamr \\
\hline Moisture & $17.2 \pm 0.09 \%$ \\
Crude protein & $2.4 \pm 0.01 \%$ \\
Crude fat & $0.8 \pm 0.04 \%$ \\
Crude fiber & $2.0 \pm 0.07 \%$ \\
Crude ash & $2.2 \pm 0.03 \%$ \\
Nitrogen free extract & $92.6 \pm 0.02 \%$ \\
Total Energy Kcal/100gm & 387.2 \\
\hline
\end{tabular}

Note. ${ }^{(1)}$ Mean values of triplicates with less than $5 \%$ coefficient of variation (dry matter basis \pm SEM). ${ }^{(2)}$ Nitrogen free extract was calculated by substraction of ash, crude protein, crude fat and crude fiber from $100 \%$.

${ }^{(3)}$ Total energy was calculated as (protein $\times 4 \mathrm{Kcal} / \mathrm{g}+$ fat $\times 9 \mathrm{Kcal} / \mathrm{g}+\mathrm{NFE} \times 4 \mathrm{Kcal} / \mathrm{g}$ ). 


\subsection{Blood Glucose Levels}

Table 4 shows serum glucose levels of normal and diabetic rats fed $0 \%$ or $10 \%$ tamr for six weeks. Feeding $10 \%$ tamr did not show significant differences $(\mathrm{P}>0.05)$ in serum glucose levels in any of the normal and insulin0treated diabetic rat groups. However, insulin-untreated diabetic rat groups fed either $0 \%$ or $10 \%$ tamr diets exhibited significantly $(\mathrm{P}<0.05)$ higher serum glucose levels compared to normal and insulin-treated diabetic rats. Feeding 10\% tamr to insulin-untreated rat groups induced significant $(\mathrm{P}<0.05)$ reduction in this variable.

Table 4. Serum glucose levels of normal and diabetic rats fed diets containing $0 \%$ or $10 \%$ Birhi Tamr for six weeks ${ }^{(1-2)}$

\begin{tabular}{lll}
\hline \multicolumn{2}{l}{ Experimental group* } & Serum glucose level mg/dl \\
\hline Normal & 0\% Tamr (Control) & $147.5 \pm 5.3^{\mathrm{a}}$ \\
& $10 \%$ Tamr (Control) & $156.3 \pm 7.6^{\mathrm{a}}$ \\
\hline Diabetic & Insulin-treated (0\% Tamr) & $227 \pm 17.6^{\mathrm{b}^{\mathrm{b}}}$ \\
& Insulin-treated (10\% Tamr) & $268.3 \pm 18.9^{\mathrm{b}}$ \\
& Insulin-Untreated (0\% Tamr) & $496 \pm 81.6^{\mathrm{c}}$ \\
& Insulin-Untreated (10\% tamr) & $315 \pm 61.1^{\mathrm{d}}$
\end{tabular}

Note. ${ }^{(1)}$ Values are given in means \pm SEM. ${ }^{(2)}$ Values in a column with different superscripts differ significantly $(\mathrm{P}<0.05)$.

\section{Discussion}

An in-depth search in the literature revealed lack of controlled studies that investigate the effect of date palm fruits on the serum glucose levels and body weight in streptozotocin-induced diabetic rats. Studies that were carried out investigate the effect of tamr on blood glucose are very limited. To our knowledge, this is the only research done to investigate the hypoglycemic effect of tamr as a nutritional entity. Such limitations make it difficult to discuss the results from a nutritional point of view. However, it may be beneficial to open new avenues of thinking for future research and studies in this field. Studies which focus on the effect of certain nutrients or chemicals that are naturally found in dates on body functions during a particular anatomic or physiologic state may be considered. Both the macro- and micro components of dates are considered. Examples of such components are vitamins, mineral elements, sugars, dietary fiber and polyphenoles. It is important to emphasize that the obtained results are related to the conditions followed by the present study and any change in these conditions, especially the date material together with the animal breed and age may affect the results.

Dates "Phoenix dactylifera" are of high content driven from the appreciable amounts of sugars including glucose and fructose found in the flesh. Additionally, dates have considerable contents of minerals, vitamins, dietary fibers and antioxidants (Hong et al., 2006). A number of studies have been conducted to investigate the effects of date consumption on human health, which have illustrated valuable results of the consumption of this fruit in maintaining well-being and in treating certain disorders (Puri et al., 2000; Miller et al., 2002; Ishrud \& Kennedy, 2005; Al-Qarawi et al., 2005).

With respect to tamr used in the present study, it was of high quality and met all the physical and chemical criteria indicated by Jordanian standard specifications (JISM, 1988) and Codex Alimentarius (1985). The maximum allowance for the defects including: blemishes, damages, and unripe dates have been determined specifically in Codex Alimentarius and Jordanian standards. There was a slight variation in the proximate nutrient composition of the date used in this study in comparison with previous studies. It may be due to the variation of date variety itself, the preservation methods, the geographical and climate differences of areas were date palm tree is grown and finally the used chemical analytical procedures (Barreveld, 1993; Al-Shahib \& Marshall, 2003).

There are no reported observations about effects of date palm fruits on blood glucose levels. Streptozotocin injection play a major role in increasing blood glucose levels (Zhong, 2001; T. SzKudelski \& K. SzKudelska, 2002; Namkoong et al., 2005). Streptozotocin is known to selectively destroy the pancreatic beta cells that produce insulin leading to hyperglycemia (Bonner-weir et al., 1981; Yang \& Wright, 2002). Streptozotocin impaires glucose homeostasis in the liver (Hidaka et al., 2002). In the present study normal rats exhibited blood glucose levels ranged from $150-180 \mathrm{mg} / \mathrm{dL}$ which goes in line with the values reported by previous studies 
(Rafferty \& MacLachlan, 1941).

In this study, blood glucose concentration tended to be lower in diabetic insulin-untreated group fed $10 \%$ tamr than the group fed $0 \%$ tamr diet. This result may be attributed to the fact that dates have low glycemic index (Ahmed et al., 1991, 1998; Famuyiwa et al., 1992; Miller et al., 2002, 2003) despite their high content of sugar and carbohydrates. Glycemic index of Birhi date is 49.7 at tamr stage. The low glycemic index of dates can be attributed to the high fructose content. Table 4 shows serum glucose levels of normal and diabetic rats fed $10 \%$ tamr for six weeks. It is shown from the table that the diabetic insulin-untreated group fed $0 \%$ tamr diet has the highest blood glucose levels.

\section{Conclusion}

Diabetic insulin-treated rats exhibited similar serum glucose levels compared to normal rats. It was noted that dietary incorporation $10 \%$ of tamr resulted in a decrease in blood glucose levels in diabetic insulin-untreated rats. Hence, an insulin-like substance in tamr, that improves the metabolic status of diabetic rats, is postulated.

\section{Acknowledgements}

The authors would like to thank Deanship of Academic Research at The University of Jordan for the financial support.

\section{References}

ADA. (2002). American Diabetes Association: Clinical practice recommendations. Expert Committee on the Diagnosis and Clasification of Diabetes Mellitus. Diabetes Care, 25(Suppl. 1), S1-147.

Ahmed, I. A., Ahmed, A. W. K., \& Robinson, R. K. (1995). Chemical composition of date varieties as influenced by the stage of ripening. Food Chemistry, 54(3), 305-309. http://dx.doi.org/10.1016/0308-8146(95)00051-J

Ahmed, M., Al-Othaimeen, A., Devol, E., \& Bold, A. (1991). Comparative responses of plasma glucose, insulin and C-peptide following ingestion of isocaloric glucose, a modified urban Saudi breakfast and dates in normal Saudi persons. Annals of Saudi Medicine, 11(4), 414-417.

Ahmed, M., Devol, E., \& Al-Othaimeen, A. (1998). Metabolic consequences of date snack before a meal: traditional Arab practice. Saudi Medical Journal, 19(3), 313-318.

Ajlouni, K., Qusous, Y., Khawaldeh, A. K., Jaddou, H., Batiehah, A., Ammari, F., ... Mashal, A. (1999). Incidence of insulin-dependent diabetes mellitus in Jordanian children aged 0-14 during 1992-1996. Acta Paediatrica Supplement, 88(427), 11-13. http://dx.doi.org/10.1111/j.1651-2227.1999.tb14334.x

Ajlouni, K., Jaddou, H., \& Batieha, A. (1998). Diabetes and impaired glucose tolerance in Jordan: Prevalence and associated risk factors. Journal of internal Medicine, 244, 317-323. http://dx.doi.org/10.1046/j.1365-2796.1998.00369.x

Al-Hooti, S. N., Sidhu, J. S., Al-Saqer, J. M., \& Al-Othman, A. (2002). Chemical composition and quality of date syrup as affected by pectinase/ cellulose enzyme treatment. Food Chemistry, 79, 215-220. http://dx.doi.org/10.1016/S0308-8146(02)00134-6

Al-Mashhadi, A. S., Al-Shalhat, A. F., Fawol, A. F., \& Abou Hamrah, A. A. (1993). Storage and preservation of dates at rutab stage. Proceedings of the Third Symposium on the Date Palm in Saudi Arabia (pp. 300-314), King Faisal University, Al-Hassa, Saudi Arabia, June 17-20, 1993.

Al-Qarawi, A. A., Abdel-Rahman, H., Ali, B. H., Mousa, H. M., \& Al- Mougy, S. A. (2005). The ameliorative effect of dates (Phoenix dactylifera L.) on etyhanol-induced gastric ulcer in rats. Journal of Ethnopharmacology, 98(3), 313-317. http://dx.doi.org/10.1016/j.jep.2005.01.023

Al-Ruqaie, I. M., \& El-Nakhal, H. (1989). "Tamaroggtt" a new product from date and Oggtt. Proceedings of the Second Symposium on the Date Palm in Saudi Arabia (pp. 133-140), King Faisal University, Al-Hassa, Saudi Arabia, March 3-6, 1986.

Al-Shahib, W., \& Marsahll, R. J. (2003). The fruits of the date palm: Its possible use as the best food for the future. International Journal of Food Science and Nutrition, 54(4), $247-259$. http://dx.doi.org/10.1080/09637480120091982

Al-Shahib, W., \& Marshall, R. J. (2002). Dietary fiber content of dates from 13 varieties of date palm Phoenix dactylifera L. International Journal of Food Science and Technology, 37, 719-721. http://dx.doi.org/10.1046/j.1365-2621.2002.00615.x

Al-Shamsi, M., Amin, A., \& Adeghate, E. (2007). The effect of vitamin C on the metabolic parameters of 
experimental diabetes mellitus. American Journal of Pharmacology and Toxicology, 2(1), 4-9. http://dx.doi.org/10.3844/ajptsp.2007.4.9

Amer, W. M. (1994). Taxonomic and documentary study of food plants in Ancient Egypt (Ph.D. Thesis, Cairo University, Egypt). Retrieved from http://www.levity.com/alchemy/islam08.html

AOAC. (1995). Official Methods of Analysis of the Association of Official Analytical Chemists (16th ed.). USA, Virginia: AOAC.

Barreveld, W. H. (1993). Date Palm Products. Rome Italy: Food and Agriculture Organization of the United Nations. Retrieved from http:// www.fao.org/docrept/t0681E/t0681e00.htm

Bonner-Weir, S., Trent, D. F., Hony, R. N., \& Weir, G. C. (1981). Responses of neonatal rat islets to streptozotocin: Limited B-cell regeneration and hyperglycemia. Diabetes, 30, 64-69. http://dx.doi.org/10.2337/diab.30.1.64

Caro, A. D., Pigo, A., Pinna, I., Fenu, P. M., \& Agabbio, M. (2004). Effect of drying conditions and storage period on polyphenolic content, antioxidant capacity, and ascorbic acid of prunes. Journal of Agricultural Food Chemistry, 25, 4780-4784. http://dx.doi.org/10.1021/jf049889j

Codex Alimentarius. (1985). Codex Standards (Codex Stan. 143: 1985): Codex Standard for Dates. http://dx.doi.org/10.1021/jf049889j

Dominique, L. M. E., Betan, H., Larsen, H., \& Lawerence, S. P. (2003). Relationship of depression to diabetes type 1 and type2: Epidemiology, biology and treatment. Biological Psychiatry, 54, 317-329. http://dx.doi.org/10.1016/S0006-3223(03)00569-9

Drisko, J. A. J., Chapman, J., \& Hunter, V. J. (2003). The use of antioxidant therapies during chemotherapy. Gynecologic Oncology, 88, 434-439. http://dx.doi.org/10.1016/S0090-8258(02)00067-7

El-Shaarawy, M. I. (1989). Dates in Saudi diet, Proceedings of the second Symposium on the Date Palm in Saudi Arabia (pp. 53-47). King Faisal University, Al-Hassa, Saudi Arabia, March 3, 1986.

Famuyiwa, O. O., El-Hazmi, M. A. F., Al-Jasser, S. J., Sulimani, R. A., Jayakumer, R. V., Al-Nuaim, A. A., \& Mekki, M. O. (1992). A comparison of acute glycemic and insulin response to dates (Phoenix dactylifera) and oral dextrose in diabetic and non-diabetic subjects. Saudi Medical Journal, 13(5), 397-402.

Gaede, P., Vaedal, P., \& Larsen, N. (2003). Multifactorial intervention and cardiovascular disease in patients with type 2 diabetes. New England Journal of Medicine, 348, 383-393. http://dx.doi.org/10.1056/NEJMoa021778

Hamad, A. M., Mustafa, A. I., \& Al-Khatani, M. S. (1983). Possibility of utilizing dates syrup as a sweetening and flavouring agent in ice cream making, Proceedings of the First Symposium on the Date Palm in Saudi Arabia (pp. 544-549), King Faisal University, Al-Hassa, Saudi Arabia, March 23-35, 1982.

Heymann, A. D., Chodick, G., Halkin, H., Karasik, A., Shalev, V., Shemer, J., \& Kokia, A. (2006). The implementation of managed care for diabetes using medical informatics in a large preferred. Diabetes Research and Clinical Practice, 71, 290-298. http://dx.doi.org/10.1016/j.diabres.2005.07.002

Hidaka, S., Yoshimatsu, H., Kondou, S., Tsuruta, Y., Oka, K., Noguchi, H., ... Sakata, T. (2002). Chronic central leptin infusion restores hyperglycemia independent of food intake and insulin level in streptozotocin-induced diabetic rats. Journal of the Federation of American Societies for Experimental Biology, 16, 509-518. http://dx.doi.org/10.1096/fj.01-0164com

Hill, J. O., \& Peters, J. C. (2002). Biomarkers and functional foods for obesity and diabetes. British Journal of Nutrition, 88(Suppl. 2), S213-S218. http://dx.doi.org/10.1079/BJN2002685.

Hong, Y. L., Tomas-Barberan, F. A., Kader, A. A., \& Mitchell, A. E. (2006). The falvonoid glycosides and procyanidin composition of Dglet Noor dates (Phoenix dactylifera). Journal of Agricutural and Food Chemistry, 54, 2405-2411. http://dx.doi.org/10.1021/jf0581776

Ishrud, O., \& Kennedy, J. F. (2005). The anti-cancer activity of polysaccharide prepared from Libyan dates $\begin{array}{lllll}\text { (Phoenix dactylifera } & \text { L.). } & \text { Carbohydrates } & \text { Polymers, } & \text { 59, }\end{array}$ http://dx.doi.org/10.1016/j.carbpol.2004.11.004

Johnson, D. V. (1998). Non-Wood Forest Products 10: Tropical Palm. Food and Agriculture Organization, Rome. Jordan Institution for Standards and Metrology (JISM). (1988). Jordanian standard specification (JS 549:1988): Fruits (Fresh) - Dates. Amman, Jordan. 
Kanarek, R., \& Ho, L. (1984). Patterns of nutrient selection in rats with streptozotocin-induced diabetes. Physiology and Behavior, 32, 639-645. http://dx.doi.org/10.1016/0031-9384(84)90319-6

Miller, C., Dunn, J., E. V., \& Hashim, I. B. (2002). Glycemic index of 3 varieties of dates. Saudi Medical Journal, 23(5), 536-538.

Miller, C., Dunn, E. V. J., \& Hashim, I. B. (2003). The glycemic index of dates and date/yoghurt mixed meals. Are dates "the candy that grows on trees"? European Journal of Clinical Nutirtion, 57, 427-430. http://dx.doi.org/10.1038/sj.ejcn.1601535

Mustafa, A. I., Hamad, A. M., \& Al-Khatani, M. S. (1983a). Date varieties for jam production. Proceedings of the First Symposium on the Date Palm in Saudi Arabia, King Faisal University (pp. 496-501), Al-Hassa, Saudi Arabia, March 23-35, 1982.

Mustafa, A. I., Hamad, A. M., Wahdan, A. N., \& Al-Khatani, M. S. (1983b). Extraction of date syrup (dibs) and its utilization in bakery products and juices, Proceedings of the First Symposium on the Date Palm in Saudi Arabia, King Faisal University (pp. 543-542), Al-Hassa, Saudi Arabia, March 23-35, 1982.

Naber, S. N. (2005). Personal communications. Al Baraka Farms.

Namkoong, C., Kim, M. S., Jang, P. G., Han, S. M., Park, H. S., \& Koh, E. H. (2005). Enhanced hypothalamic AMP-activated protein kinase activity contributes to hyperphagia in diabetic rats. Diabetes, 54, 63-68. http://dx.doi.org/10.2337/diabetes.54.1.63

Puri, A., Sahai, R., Singh, K. L., Saxena, R. P., Tandon, J. S., \& Saxena, K. C. (2000). Immunostimulant activity of dry fruits and plant material used in Indian traditional medical system for mothers after child birth and invalids. Journal of Ethnopharmacology, 71, 89-92. http://dx.doi.org/10.1016/S0378-8741(99)00181-6

Rafferty, M. A., \& MacLachlan. (1941). Influence of increased environmental temperature on blood sugar, liver glucose, and absorption in rats following the administration of glucose and starch. Journal of Biological Chemistry, 140, 167-170.

Reeves, G. P. (1997). Components of the AIN-93 diets as improvements in the AIN-79A diet. Journal of Nutrition, 127, 838S-841S.

Roberfroid, M. B. (2000). Defining Functional Foods. In G. R. Gibson, \& C. Williams (Eds.), Functional Foods: Concept to Product (pp. 9-27), Cambridge: Woodhead publishing limited.

Sawaya, W. N., Khatchadourian, H. H., Khalil, J. K., \& Al-Shalhat, A. F. (1989). Processing of dates into date chutney. Proceedings of the Second Symposium on the Date Palm in Saudi Arabia (pp. 105-111), King Faisal University, Al-Hassa, Saudi Arabia, March 3-6, 1986.

SzKudelski, T., \& SzKudelska, K. (2002). Streptozotocin induces lipolysis in rat adipocytes in vitro. Physiological Research, 51, 255-259.

Vayalil, P. K. (2002). Antioxidant and antimutagenic properties of aqueous extract of date fruit (Phoenix dactylifera L. Arecaceae). Journal of Agriculture and Food Chemistry, 50(3), 610-617. http://dx.doi.org/10.1021/jf010716t

Yamada, R., Griggio, M. A., \& Luz, J. (2002). Energy balance of pregnant diabetic rats. British Journal of Nutrition, 87, 509-515. http://dx.doi.org/10.1079/BJN2001520

Yang, H., \& Wright, J. R. (2002). Human beta cells are exceedingly resistant to Streptozotocin in vivo. Endocrinology, 143, 2491-2495. http://dx.doi.org/10.1210/endo.143.7.8901

Yousif, A. K., Ahmad, S. S., \& Mirandilla, W. A. (1989). Development of a nutritious beverage from concentrated date syrup and powdered milk. Proceedings of the Second Symposium on the Date Palm in Saudi Arabia (pp. 121-130), King Faisal University, Al-Hassa, Saudi Arabia, March 3-6, 1982.

Zhong, Y., Ahmed, S., Grupp, I. L., \& Matlib, A. (2001). Altered SR protein expression associated with contractile dysfunction in diabetic rat hearts. AJP-Heart and Circulatory Physiology, 281, H1137-1147.

\section{Copyrights}

Copyright for this article is retained by the author(s), with first publication rights granted to the journal.

This is an open-access article distributed under the terms and conditions of the Creative Commons Attribution license (http://creativecommons.org/licenses/by/3.0/). 